\title{
EFEK MEDIASI WORK-FAMILY CONFLICT TERHADAP STRES KERJA PADA IBU BEKERJA DI RUMAH SELAMA PANDEMI COVID-19
}

\author{
Abdu Alifah \\ IPB University, abdualifahalifah@apps.ipb.ac.id
}

\begin{abstract}
ABSTRAK
Ibu yang bekerja di rumah mengalami stres kerja akibat work-family conflict (konflik pekerjaankeluarga) selama pandemi Covid-19. Sementara penelitian-penelitian terdahulu meninjau workfamily conflict dan stres kerja secara parsial, penelitian ini mengajukan model struktur kausalitas yang lebih komprehensif dengan menganalisis pengaruh dukungan pasangan dan dukungan organisasi terhadap stres kerja pada ibu bekerja di rumah selama pandemi Covid-19 melalui mediasi work-family conflict. Penelitian ini menggunakan teknik purposive sampling dengan melibatkan 57 responden dengan kriteria ibu yang bekerja di rumah selama pandemi Covid-19, berdomisili di Jabodetabek, dan memiliki anak minimal satu. Analisis data dalam penelitian ini menggunakan teknik analisis jalur (path analysis) dengan dua model analisis langsung dan tidak langsung. Hasil penelitian menunjukkan bahwa dukungan pasangan dan dukungan organisasi secara langsung berpengaruh negatif terhadap work-family conflict, namun dukungan pasangan dan dukungan organisasi tidak berpengaruh secara langsung terhadap stres kerja. Work-family conflict berpengaruh positif secara langsung terhadap stres kerja, sementara dukungan pasangan dan dukungan organisasi berpengaruh negatif terhadap stres kerja melalui mediasi work-family conflict. Dengan demikian, stres kerja yang dialami oleh ibu bekerja di rumah selama pandemi Covid-19 akibat work-family conflict dapat dikurangi dengan meningkatkan dukungan pasangan dan dukungan organisasi.
\end{abstract}

Kata Kunci: dukungan organisasi, dukungan pasangan, stres kerja, work-family conflict

\begin{abstract}
Teleworking mothers in Indonesia have been stressed due to work-family conflicts during the Covid-19 pandemic. Whilst most scholars likely have been studied work-family conflict and work stress partially, this study proposed a more comprehensive structural model of causality by analyzing the effect of spousal and organizational support toward work stress on teleworking mothers during the Covid-19 pandemic through the mediation of work-family conflict. This study used a purposive sampling technique in collecting 57 respondents that appropriated to the criteria of study such as teleworking mother during the Covid-19 pandemic, live in Jabodetabek, and possess one child or more. This study used path analysis with two models of direct and indirect. The results indicated that spousal support and organizational support directly and negatively affected work-family conflict, but did not directly affect work stress. Work-family conflict directly and positively affected work stress, while spousal and organizational support indirectly and negatively affected work stress through the mediation of work-family conflict. Therefore, teleworking mothers who have been stressed during the pandemic due to work-family conflicts are recommended to improve their spousal dan organizational support in reducing their level of work stress.
\end{abstract}

Keywords: organizational support, spousal support, work-family conflict, work stress

Naskah diterima : 29-01-2021, Naskah dipublikasikan : 31-03-2021 


\section{PENDAHULUAN}

Sejak meningkatnya jumlah kasus positif yang terinfeksi Covid-19, pemerintah Indonesia mulai memberlakukan berbagai kebijakan pencegahan penyebaran virus tersebut seperti himbauan untuk mengurangi aktivitas di luar rumah, penjagaan jarak (physical distancing), hingga pembatasan sosial berskala besar (PSBB I dan PSBB II) terutama di beberapa kota dengan jumlah kasus positif yang tinggi. Pemberlakuan kebijakan-kebijakan tersebut berdampak pada berbagai bidang salah satunya adalah pekerjaan yang selanjutnya memaksa perusahaan untuk mengadopsi gaya kerja baru, yakni bekerja dari rumah (WFH). Berdasarkan data Survei Sosial Demografi Dampak Covid-19, sebanyak 39,09\% karyawan bekerja dari rumah secara penuh, $34,76 \%$ bekerja dari rumah tetapi masih diselingi dengan jadwal masuk kantor dan sisanya masuk seperti biasa sebanyak $7,07 \%$ serta $19,06 \%$ merupakan pekerjaan yang tidak memungkinkan untuk dilakukan di rumah (Badan Pusat Statistik, 2020). Data lain dari Survei Dampak Darurat Covid-19 terhadap Buruh/Karyawan oleh P2 Kependudukan \& LD-UI (2020) juga menunjukan bahwa karyawan yang bekerja dari rumah mencapai $51 \%$ sejak ditetapkannya himbauan tersebut.

Pandemi Covid-19 menyebabkan banyak implikasi fenomena baru yang kemudian banyak diteliti, salah satunya adalah penelitian Coyne et al., (2020) yang menjelaskan bahwa banyak orang tua mengalami stres akibat benturan peran, tanggung jawab dan ekspektasi baik sebagai orang tua, pasangan, pekerja sekaligus guru karena anak-anak melakukan kegiatan belajar di rumah. Pembatasan sosial akibat pandemi Covid-19 memaksa orang tua harus memainkan berbagai peran dengan sumber daya yang sangat terbatas karena mereka kehilangan bantuan dari sekolah, tetangga dan anggota keluarga besar serta lingkungan sekitar (Chung, Chan, et al., 2020). Penelitian (Morelli et al., 2020) memperkuat pernyataan bahwa dalam kondisi saat ini orang tua secara tiba-tiba menjadi satu-satunya rujukan bagi anak-anak karena sumber daya dan bantuan terputus sehingga menyebabkan stres akibat terlalu banyak peran. Pada akhirnya, banyak orang tua yang tidak puas karena tidak mampu menyeimbangkan antara pekerjaan dan keluarga terutama sekali bagi ibu yang bekerja.

Penelitian Chandola et al., (2020) menyebutkan bahwa stres ibu yang bekerja dengan dua anak meningkat $40 \%$ lebih tinggi daripada rata-rata orang selama pandemi Covid-19 di Inggris. Sementara di Amerika Serikat, orang tua dari anak di bawah usia 18 tahun mengalami lebih banyak stres akibat pandemi Covid-19 dan sekitar 57\% ibu yang bekerja mengalami penurunan kesehatan mental karena menanggung sebagian besar beban yang tidak proporsional dengan pasangannya (Power, 2020). Di Australia, penelitian yang dilakukan oleh (Craig \& Churchill, 2020) menunjukkan bahwa beban ibu maupun ayah yang bekerja sama-sama meningkat selama pandemi Covid-19, namun demikian tetap lebih tinggi beban yang dialami oleh ibu yang bekerja karena meningkat sekitar 2 jam 30 menit dibanding beban ayah yang bekerja hanya meningkat 1 jam 30 menit.

Sementara di Indonesia, penelitian Chairani (2020) menyebutkan bahwa kebanyakan perempuan yang bekerja di Indonesia cenderung mengalami beban ganda yang lebih karena narasi budaya patriarki yang mengarahkan bahwa pekerjaan domestik-seperti halnya pekerjaan rumah tangga dan mengasuh anak-merupakan tanggung jawab utama perempuan. Penelitian Megatsari et al., (2020) selanjutnya menunjukkan bahwa terdapat perbedaan tingkat kecemasan yang sangat signifikan antara laki-laki dan perempuan di Indonesia selama pandemi Covid-19 dengan sebaran 58,1\% perempuan mengalami kecemasan tingkat tinggi, 40,7\% mengalami kecemasan tingkat sedang, serta sisanya $1,01 \%$ berada di tingkat kecemasan rendah. Selain itu, penelitian ini juga meninjau tingkat kecemasan berdasarkan status pernikahan. Pada kategori kelompok dengan tingkat kecemasan tinggi, 50,5\% reponden berstatus menikah, 46,8\% berstatus belum menikah, dan $2,7 \%$ berstatus bercerai. Dengan demikian, perempuan yang telah menikah atau menjadi seorang ibu adalah kelompok yang paling banyak mengalami stres karena 
menjadi pihak yang paling banyak menanggung beban dan tuntutan selama pemberlakuan sistem kerja dari rumah (WFH) sekaligus juga harus mengurus rumah tangga dan anak yang juga turut belajar dari rumah sehingga akhirnya menyebabkan work-family conflict atau konflik peran antara pekerjaan-keluarga.

Penelitian yang mengkaji keterkaitan antara work-family conflict dan stres kerja telah banyak dilakukan namun dalam perspektif yang parsial, misalnya penelitian (Agustina \& Sudibya, 2018), Gusti et al., (2016), Jamadin et al., (2015), Bazana \& Dodd (2013) serta Hammer et al., (1996). Di sisi lain, teori model work-home resource (W-HR) dari Brummelhuis \& Bakker (2012) mampu menjelaskan keterkaitan tersebut secara lebih komprehensif namun masih belum banyak dilakukan penelitian explanatori lebih lanjut. Teori model work-home resource (W-HR) menunjukan bahwa akumulasi dan interaksi antar sumber daya (personal, kontekstual, macro dan kunci) mempengaruhi hasil work-home interface dan akhirnya menyebabkan terjadinya work-family conflict serta meningkatkan kecenderungan untuk mengalami stres.

Selanjutnya, peneliti mencoba untuk mengajukan model struktur kausalitas yang lebih komprehensif dalam keterkaitan antara work-family conflict dan stres kerja dengan meninjau dukungan pasangan dari domain rumah/keluarga (home) dan dukungan organisasi dari domain pekerjaan (work) yang merupakan bagian dari sumber daya kontekstual dalam teori model work-home resource (W-HR). Dukungan pasangan dan dukungan organisasi merupakan sumber daya kontekstual yang masih dimiliki oleh ibu yang bekerja di rumah pada situasi pandemi Covid-19 ini. Oleh karena itu, penelitian ini menjadi penting untuk melihat apakah dukungan pasangan dan dukungan organisasi menjadi faktor yang dapat menekan tingkat work-family conflict yang selama ini menjadi pemicu terjadinya stres kerja pada ibu yang bekerja di rumah selama Covid-19. Penelitian ini selanjutnya bertujuan untuk menganalisis pengaruh dukungan pasangan dan dukungan organisasi terhadap stres kerja pada ibu yang bekerja di rumah selama pandemi Covid-19 melalui mediasi work-family conflict.

\section{KAJIAN LITERATUR \\ Teori Work-Home Resource (W-HR)}

Kajian mengenai work-family conflict merupakan bagian dari kerangka konseptual model work-home resource (W-HR) dari Brummelhuis \& Bakker (2012)-yang merupakan pengembangan teori conservation of resource atau COR (Hobfoll, 2002). Teori COR merupakan salah satu teori paling berpengaruh yang menjelaskan kaitan antara stres dan kesejahteraan, yakni bagaimana seseorang bereaksi terhadap stres yang mereka hadapi di lingkungan mereka dan bagaimana hal itu kemudian mempengaruhi kesejahteraan mereka. Asumsi teori COR adalah bahwa orang berusaha untuk mendapatkan, mempertahankan, dan melindungi sumber daya yang mereka miliki. Ketika sumber daya yang mereka miliki ini hilang atau berkurang, stres akan muncul sebagai konsekuensinya (Hobfoll, 2002).

Brummelhuis \& Bakker (2012) kemudian membagi sumber-daya-sumber tersebut dalam empat kategori. Pertama, Sumber daya individu (personal resource) yang berasal dalam diri atau internal seseorang seperti kemampuan, pengetahuan, kemampuan kognitif, energi dan lain sebagainya. Kedua, Sumber daya kontekstual (contextual resource) berada di luar diri atau eksternal individu dan secara umum ditemukan dalam konteks sosial seperti dukungan sosial, dukungan pasangan, dukungan organisasi, dukungan rekan kerja, dan dukungan lain yang datang dari orang-orang yang berperan penting dalam hidup seseorang. Ketiga, sumber daya makro (macro resource) yang mengacu pada karakteristik sistem ekonomi, sosial, dan budaya yang lebih besar di mana seseorang berada seperti budaya gotong royong dan saling membantu. Keempat, sumber daya kunci (key resource) yang mengacu bagaimana seseorang mengelola, 
memilih, merubah dan menggunakan sumber daya lain yang dimilikinya seperti ciri kepribadian, motivasi, optimisme, dan lain sebagainya.

Dalam kerangka work-home resource Brummelhuis \& Bakker (2012), akumulasi dan interaksi antar sumber daya tersebut akan menggambarkan dua proses utama, yakni spiral keuntungan di mana seseorang berhasil mengumpulkan banyak sumber daya dan membawa pada pengayaan pekerjaan-rumah (work-home enrichment) sehingga akhirnya dapat menekan tingkat stres, atau spiral kerugian di mana seseorang kehabisan sumber daya saat mengatasi masalah yang muncul kemudian menjadi konflik pekerjaan-rumah (work-home conflict) dan akhirnya menyebabkan tingkat stres tinggi. Dalam penelitian ini, peneliti mencoba untuk meninjau lebih lanjut dukungan pasangan yang berasal dari domain rumah (home) dan dukungan organisasi yang berasal dari domain pekerjaan (work) sebagai sumber daya kontekstual yang dapat mempengaruhi work-family conflict dan implikasinya terhadap stres kerja dengan mengembangkan hipotesis sebagai berikut.

\section{Hubungan Dukungan Pasangan dan Dukungan Organisasi dengan Work-Family Conflict}

Penelitian sebelumnya yang dilakukan Aycan \& Eskin (2005) menunjukkan bahwa dukungan pasangan memiliki hubungan yang erat secara negatif dengan work-family conflict. Penelitian lain yang mendukung hasil temuan terkait pengaruh dukungan pasangan terhadap work-family conflict adalah penelitian Burke \& Greenglass (1999) serta Erdwins et al., (2001). Penelitian Halbesleben et al., (2012) menjelaskan bahwa dukungan pasangan dapat mengurangi berbagai hasil negatif (misalnya work-family conflict) dan dapat menjadi sumber daya yang sangat penting bagi mereka yang menjalankan peran ganda seperti ibu yang bekerja. Penelitian Turner \& Mariani (2016) menunjukkan bahwa dukungan organisasi memainkan peran penting terhadap karyawan dalam menyeimbangkan pekerjaan dan tanggung jawab keluarga. Sementara penelitian yang dilakukan oleh Anderson (2017) menjelaskan bahwa dukungan organisasi secara signifikan dapat menurunkan tingkat work-family conflict pada karyawan yang memiliki peran ganda.

H1. Dukungan pasangan berpengaruh negatif secara langsung terhadap work-family conflict

H2. Dukungan organisasi berpengaruh negatif secara langsung terhadap work-family conflict

\section{Hubungan Dukungan Pasangan dan Dukungan Organisasi dengan Stres Kerja}

Penelitian Adams et al., (1996) serta Burke \& Traavik (2016) menjelaskan bahwa dukungan pasangan memainkan peran penting dalam mengurangi efek stres kerja. Sementara penelitian Leung et al., (2008) menunjukkan bahwa dukungan organisasi merupakan salah satu faktor yang efektif dalam mengurangi stres kerja dan kelelahan kerja (burnout) yang dialami oleh karyawan.

H3. Dukungan pasangan berpengaruh negatif secara langsung terhadap stres kerja

H4. Dukungan organisasi berpengaruh negatif secara langsung terhadap stres kerja

\section{Hubungan antara Work-Family Conflict dengan Stres Kerja}

Beberapa penelitian yang dilakukan terkait hubungan antara work-family conflict dan stres kerja, salah satunya adalah penelitian Agustina \& Sudibya (2018) yang menyatakan bahwa work-family conflict berpengaruh secara positif dengan stres kerja dan menjadi variabel mediasi dalam mempengaruhi secara negatif terhadap kinerja seseorang dalam pekerjaannya dalam taraf yang signifikan. Penelitian lainnya yang menunjukan hasil yang sama adalah penelitian Gusti et al., (2016), Jamadin et al., (2015), Bazana \& Dodd (2013) serta Hammer et al., (1996) yang kesemuanya menunjukan pengaruh positif antara work-family conflict dengan stres kerja.

H5. Work-family conflict berpengaruh secara positif terhadap stres kerja 


\section{Hubungan antara Dukungan Pasangan, Dukungan Organisasi, Work-Family Conflict dan Stres Kerja}

Penelitian yang dilakukan oleh Brummelhuis \& Bakker (2012) terkait work-home resources (W-HR)-pengembangan teori COR (Hobfoll, 2002)-menunjukan bahwa sumber daya-sumber daya (personal, kontekstual, macro dan kunci) mempengaruhi hasil work-home interface dan akhirnya menyebabkan terjadinya work-family conflict serta meningkatkan kecenderungan untuk mengalami stres. Dalam hal ini, peneliti mengembangkan hipotesis bahwa dukungan pasangan dan dukungan organisasi yang merupakan bagian dari sumber daya kontekstual dapat mengurangi stres kerja secara tidak langsung melalui work-family conflict yang dialami oleh ibu yang bekerja di rumah selama pandemi Covid-19. Untuk lebih mudah memahami arah hipotesis di atas, berikut adalah kerangka penelitian ini:

H6. Dukungan pasangan berpengaruh negatif secara tidak langsung terhadap stres kerja melalui mediasi work-family conflict

H7. Dukungan organisasi berpengaruh negatif secara tidak langsung terhadap stres kerja melalui mediasi work-family conflict

\section{METODE PENELITIAN \\ Data dan Sampel}

Proses pengambilan data penelitian dilakukan selama bulan Desember 2020 dengan menggunakan media survey online dan kuesioner dibuat melalui google-formulir. Teknik penarikan contoh atau sampel dalam penelitian ini menggunakan purposive sampling. Oleh sebab itu, responden terlebih dahulu diberikan pertanyaan screening yang digunakan untuk kebutuhan seleksi agar sesuai dengan kriteria penelitian sebelum mengisi kuesioner. Adapun kriteria responden dalam penelitian ini meliputi: seorang ibu yang bekerja di rumah selama pandemi Covid-19, berdomisili di Jabodetabek dan memiliki anak minimal satu. Pemilihan kriteria domisili Jabodetabek berdasarkan pertimbangan bahwa kota-kota tersebut merupakan kota dengan kasus positif tertinggi dan menerapkan PSBB. Selanjutnya sebanyak 94 responden yang mengisi kuesioner yang disebarkan melalui berbagai media sosial seperti whatsapp, instagram, linkedin dan facebook. Namun setelah melalui proses seleksi, hanya terdapat 57 responden yang sesuai dengan kriteria penelitian. Beberapa responden yang tidak memenuhi kriteria disebabkan karena 1) responden berjenis kelamin laki-laki, 2) responden belum menikah, 3) responden tidak memiliki anak, dan 4) responden tinggal di luar daerah Jabodetabek.

\section{Alat Ukur}

Kuesioner penelitian terdiri dari 9 pertanyaan screening dan 58 pernyataan dalam skala likert dengan rentang jawaban dari 1 sampai 5 . Kuesioner penelitian terdiri dari skala stres kerja (18 butir aitem), work-family conflict (21 butir aitem), dukungan pasangan (6 butir aitem) dan dukungan organisasi (18 butir aitem).

\section{Stres kerja}

Skala stres kerja dalam penelitian ini menggunakan Job Stres Scale (JSS) yang dikembangkan oleh Shukla \& Srivastava (2016). Pemilihan JSS untuk mengukur tingkat stres kerja dalam penelitian ini berdasarkan pertimbangan bahwa JSS mampu mengkur stres kerja lebih komprehensif dibandingkan dengan alat ukur stres kerja lainnya. JSS mengukur stres kerja melalui empat dimensi, yakni dimensi stres kerja, dimensi konflik ekspektasi kerja, dimensi dukungan rekan kerja dan dimensi keseimbangan kehidupan-kerja dengan total reliabilitas alpha cronbach 0.81. Keseluruhan aitem JSS berjumlah 18 butir. Hasil pengujian validitas menunjukkan bahwa terdapat empat aitem pernyataan yang tidak memenuhi standar validitas (p>r Tabel 0,2564) dengan masing-masing nilai rHitung 0,069 (P1.5), 0,005 (P1.14), -0,410 (P1.15) dan 0,053 (P1.16) sehingga total pernyataan yang valid untuk diujikan berjumlah 14 
butir. Sementara hasil pengujian reliabilitas menunjukkan nilai alpha cronbach 0,855 , yang berarti skala ini sangat reliabel karena $\mathrm{p}>r$ Kritis 0,600 .

\section{Work-Family Conflict}

Work-family conflict diukur dengan menggunakan Work-Family Conflict Scale (WFCS) dari penelitian (Thomas \& Ganster, 1995) yang dikembangkan dari dua skala yang berbeda. Skala pertama (13 butir) dikembangkan dari penelitian Bohen \& Viveros-Long (1981) yang berfokus pada pengukuran aspek keseimbangan kerja dan pengasuhan anak. Sementara skala kedua (7 butir) dikembangkan dari Kopelman et al., (1983) yang berfokus pada aspek konflik peran ganda. Total aitem WFCS berjumlah 21 butir dengan nilai alpha cronbach 0,92. Hasil pengujian validitas dalam penelitian ini menunjukkan bahwa semua item lolos uji validitas karena memenuhi standar validitas ( $p>r$ Tabel 0,2564). Sementara hasil uji reliabilitas menunjukkan nilai alpha cronbach yang sangat tinggi, yakni 0,945 ( $>$ r Kritis 0,600 ).

\section{Dukungan Pasangan}

Skala dukungan pasangan dalam penelitian ini merupakan hasil adaptasi dari skala Family Support Inventory for Workers (FSIW) yang dikembangkan oleh King et al., (1995) FSIW mengukur aspek dukungan emosional dan dukungan instrumental. Masing-masing aspek tersebut memiliki nilai alpha cronbach 0,97 untuk aspek dukungan emosional dan 0,95 untuk dukungan instrumental. Total aitem yang digunakan dalam penelitian ini berjumlah 18 butir. Hasil pengujian validitas menunjukkan bahwa semua aitem valid karena memenuhi standar validitas ( $>r$ Tabel 0,2564$)$. Sementara hasil uji reliabilitas menunjukkan nilai alpha cronbach yang sangat tinggi, yakni 0,947 ( $\mathrm{p}>$ r Kritis 0,600 ).

\section{Dukungan Organisasi}

Pengukuran dukungan organisasi menggunakan skala yang dikembangkan oleh Wu et al., (2018) dengan menggabungkan skala dari penelitian Eisenberger et al., (1986) terkait indikator dukungan supervisor, Hao et al., (2016) terkait identifikasi nilai yang dimiliki oleh karyawan terhadap dukungan organisasi dan Yang et al., (2018) terkait perhatian yang diberikan karyawan terhadap organisasi. Total aitem dalam skala ini berjumlah 6 butir dengan nilai alpha cronbach 0,94 . Hasil pengujian validitas menunjukkan bahwa semua aitem valid karena memenuhi standar validitas ( $\mathrm{p}>r$ Tabel 0,2564). Sementara hasil uji reliabilitas menunjukkan nilai alpha cronbach yang cukup tinggi, yakni 0,758 ( $\mathrm{p}>$ r Kritis 0,600 ).

Tabel 1. Uji Reliabilitas

\begin{tabular}{|l|l|l|l|}
\hline Variabel & $\mathbf{r}_{\text {alpha }}$ & $\mathbf{r}_{\text {kritis }}$ & Keterangan \\
\hline Stress Kerja & 0.855 & 0,600 & Reliabel \\
\hline WFC & 0.945 & 0,600 & Reliabel \\
\hline Dukungan Organisasi & 0.758 & 0,600 & Reliabel \\
\hline Dukungan Pasangan & 0.947 & 0,600 & Reliabel \\
\hline
\end{tabular}




\section{Metode Analisis Data}

Metode analisis data yang digunakan dalam penelitian ini adalah analisis jalur (path analysis) dengan menggunakan SPSS 23. Analisis jalur merupakan bagian dari analisis regresi tingkat lanjut untuk melihat pengaruh antar variabel yang lebih kompleks atau multiregresi (Lleras, 2004). Dalam penelitian ini, analisis jalur menggunakan model jalur I dan II untuk melihat perbandingan pengaruh langsung variabel dukungan pasangan dan dukungan organisasi (variabel eksogen) terhadap variabel stres kerja (endogen) dan pengaruh tidak langsung variabel dukungan pasangan dan dukungan organisasi (variabel eksogen) terhadap variabel stres kerja (endogen) melalui work-family conflict sebagai variabel mediasi. Analisis jalur membutuhkan syarat uji asumsi klasik yang terdiri dari uji normalitas, uji heterokedasitas, multikolinearitas dan uji autokorelasi.

\section{PEMBAHASAN}

\section{Analisis Deskripsi Demografi}

Dalam penelitian ini, secara domisili sebaran responden paling banyak berasal dari daerah Bogor (46\%), sisanya berasal dari daerah Tangerang (26\%), Jakarta (14\%), serta Bekasi dan Depok dengan masing-masing sebanyak $7 \%$. Sementara dari aspek usia pernikahan, responden paling banyak dalam penelitian ini adalah ibu dengan usia pernikahan 0-5 tahun dan 6-10 tahun dengan masing-masing persentase sebesar 35\%, selainnya adalah ibu dengan usia pernikahan 11-15 tahun (16\%), 16-20 tahun (5\%), 21-25 tahun (5\%) dan 16-30 tahun (4\%). Ibu dengan 2 anak merupakan responden terbanyak (47\%), ibu dengan 1 anak (37\%) dan sisanya (16\%) adalah ibu dengan 3 anak atau lebih. Sebaran responden juga ditinjau dari segi apakah anak yang dimiliki oleh responden melakukan kegiatan belajar dari rumah (SFH) atau tidak. Terdapat 77\% responden dengan anak yang melakukan kegiatan belajar dari rumah dan sisanya hanya $23 \%$ responden dengan anak yang tidak melakukan kegiatan demikian. Sebaran Responden dengan pasangan yang bekerja di rumah dalam penelitian ini hampir berimbang dengan responden dengan pasangan yang bekerja di kantor (WFO), yakni dengan sebaran masingmasing sebanyak 53\% dan 47\%. Selain itu, responden lebih banyak berasal dari struktur rumah tangga yang tidak memiliki pembantu rumah tangga (68\%) dibanding yang memiliki pembantu rumah tangga (39\%).

Tabel 2. Sebaran Demografi Responden dan Deskripsi Statistik Variabel

\begin{tabular}{|l|l|l|l|l|}
\hline Demografi & N (57) & Persentase (100\%) & M & SD \\
\hline Domisili (Jabodetabek) & 8 & $14 \%$ & & \\
\hline Jakarta & 26 & $46 \%$ & & \\
Bogor & 4 & $7 \%$ & & \\
Depok & 15 & $26 \%$ & & \\
Tangerang & 4 & $7 \%$ & & \\
Bekasi & 20 & $35 \%$ & & \\
\hline Usia Pernikahan & 20 & $35 \%$ & & \\
\hline 0-5 tahun & 9 & $16 \%$ & & \\
6-10 tahun & 3 & $5 \%$ & & \\
11-15 tahun & 3 & $5 \%$ & & \\
16-20 tahun & 2 & $4 \%$ & & \\
21-25 tahun & \multicolumn{5}{|l|}{} & \\
J-30 tahun & 21 & $37 \%$ & & \\
\hline Jumlah Anak & 27 & $47 \%$ & & \\
\hline 2 & 9 & $16 \%$ & & \\
3> & 9 &
\end{tabular}




\section{p-ISSN (2088-219X) \\ e-ISSN (2716-3830)}

JURNAL EKOBIS: EKONOMI, BISNIS \& MANAJEMEN

Vol 11 Nomor 1 (2021)

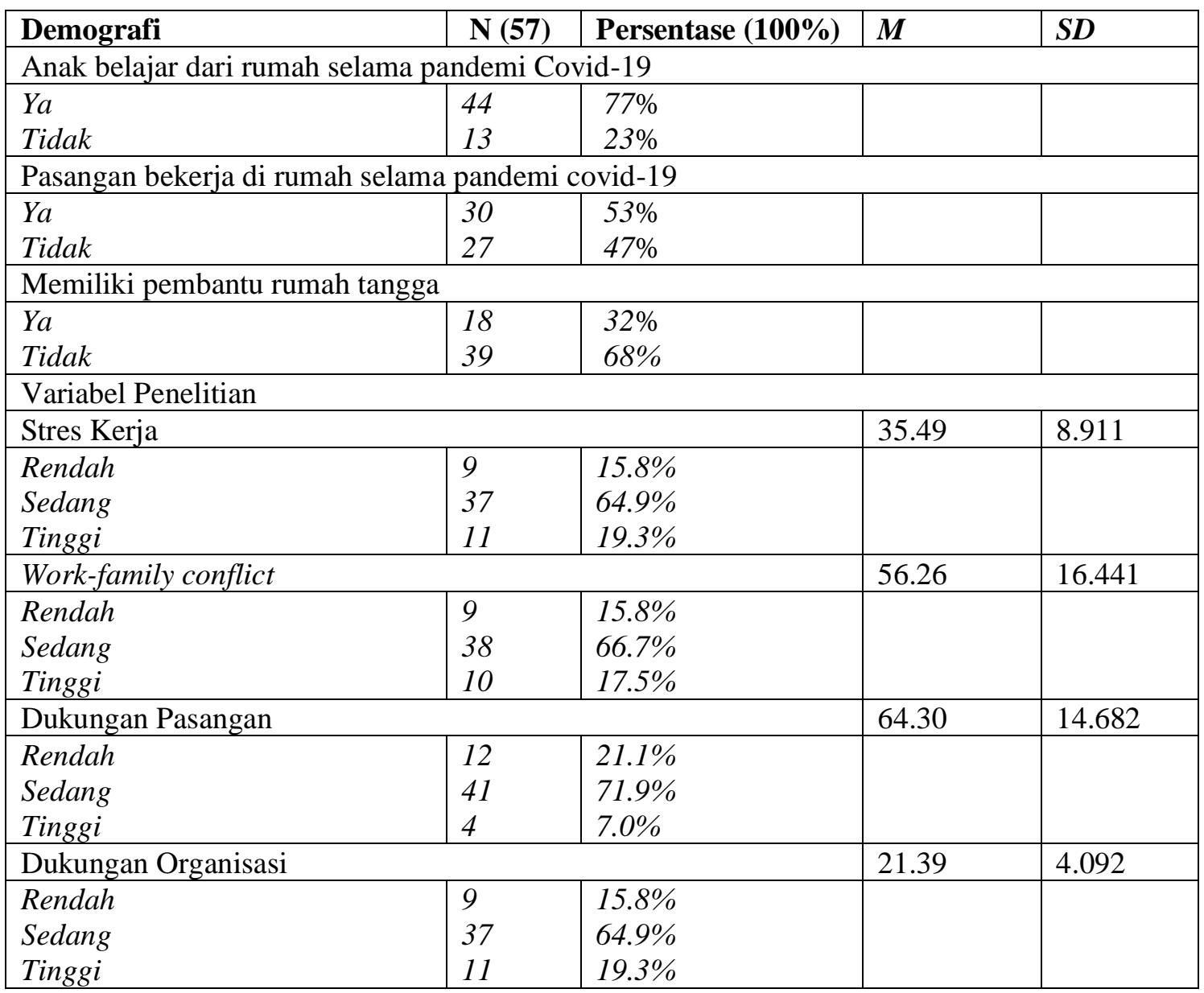

Hasil Uji Analisis Jalur (Path Analysis)

Analisis yang digunakan dalam penelitian ini adalah analisis jalur (path analysis). Oleh karena itu, uji asumsi klasik yang terdiri dari uji normalitas, uji heterokedasitas, multikolinearitas dan uji autokorelasi diperlukan sebelum pengujian hipotesis.

Tabel 3. Hasil Uji Asumsi

\begin{tabular}{|c|c|c|c|c|}
\hline Uji Asumsi & $\mathbf{N}$ & Jenis Tes & Nilai $(p)$ & Keterangan \\
\hline $\begin{array}{ll}\text { Uji } & \text { Normalitas } \\
\text { Residual } & \end{array}$ & 57 & $\begin{array}{l}\text { One-Sample } \\
\text { Kolmogorov- } \\
\text { Smirnov Test }\end{array}$ & $\begin{array}{l}0,71 \\
(\mathrm{p}>0,05)\end{array}$ & $\begin{array}{l}\text { Data } \\
\text { berdistribusi } \\
\text { normal }\end{array}$ \\
\hline \multicolumn{5}{|l|}{ Uji heterokedasitas } \\
\hline Work-family conflict & 57 & \multirow{3}{*}{ Glejser Test } & $0,328(\mathrm{p}>0,05)$ & $\begin{array}{l}\text { Tidak ada gejala } \\
\text { heterokedasitas }\end{array}$ \\
\hline Dukungan Pasangan & 57 & & $0,656(\mathrm{p}>0,05)$ & $\begin{array}{l}\text { Tidak ada gejala } \\
\text { heterokedasitas }\end{array}$ \\
\hline Dukungan Organisasi & 57 & & $0,419(\mathrm{p}>0,05)$ & $\begin{array}{l}\text { Tidak ada gejala } \\
\text { heterokedasitas }\end{array}$ \\
\hline \multicolumn{5}{|l|}{ Uji Multikolinearitas } \\
\hline \multirow{2}{*}{ Work-family conflict } & \multirow[b]{2}{*}{57} & Tolerance & $0,760(p>0,10)$ & \multirow{2}{*}{$\begin{array}{l}\text { Tidak ada gejala } \\
\text { Multikoleniarita } \\
\text { s }\end{array}$} \\
\hline & & $V I F$ & $1,316(\mathrm{p}<10,00)$ & \\
\hline Dukungan Pasangan & 57 & Tolerance & $0,807(\mathrm{p}>0,10)$ & Tidak ada gejala \\
\hline
\end{tabular}




\begin{tabular}{|c|c|c|c|c|}
\hline Uji Asumsi & $\mathbf{N}$ & Jenis Tes & Nilai $(p)$ & Keterangan \\
\hline & & $V I F$ & $1,239(\mathrm{p}<10,00)$ & $\begin{array}{l}\text { Multikoleniarita } \\
\text { s }\end{array}$ \\
\hline \multirow[b]{2}{*}{ Dukungan Organisasi } & \multirow{2}{*}{57} & Tolerance & $1,203(\mathrm{p}>0,10)$ & \multirow{2}{*}{$\begin{array}{l}\text { Tidak ada gejala } \\
\text { Multikoleniarita } \\
\text { s }\end{array}$} \\
\hline & & $V I F$ & $1.316(\mathrm{p}<10,00)$ & \\
\hline \multicolumn{5}{|l|}{ Uji Autokorelasi } \\
\hline Autokorelasi Positif & 57 & \multirow{2}{*}{$\begin{array}{l}\text { Durbin-Watson } \\
\text { Test }\end{array}$} & $\begin{array}{l}2.138 \\
(\mathrm{~d}>\mathrm{dU} 1,684)\end{array}$ & \multirow{2}{*}{$\begin{array}{l}\text { Tidak ada gejala } \\
\text { Autokorelasi } \\
\text { baik positif } \\
\text { maupun negatif }\end{array}$} \\
\hline Autokorelasi Negatif & 57 & & $\begin{array}{l}1,862 \\
(4-d>d U 1,684)\end{array}$ & \\
\hline
\end{tabular}

Berdasarkan data pada tabel 3, maka dapat disimpulkan bahwa semua variabel lolos uji asumsi klasik karena data berdistribusi normal $(0,71>0,05)$ serta tidak menunjukan adanya gejala heterokedasitas (Work-family conflict: 0,328>0,05; Dukungan Pasangan: 0,656 > 0,05; Dukungan Organisasi: 0,419>0,05), gejala multikolinearitas (Work-family conflict: Tolerance $0,760>0,10$ \& VIF 1,316 < 10,00; Dukungan Pasangan: Tolerance 0,807 > 0,10 \& VIF 1,239< 10,00; Dukungan Organisasi: Tolerance $1,203>0,10 \& V I F 1.316<10,00$ ) dan gejala autokorelasi (Autokorelasi Positif: d $2.138>$ dU 1,684 dan Autokorelasi Negatif: 4 - d 1,862 > dU 1,684).

Tabel 4. Hasil Uji Analisis Jalur

\begin{tabular}{|l|l|l|l|l|}
\hline \multirow{2}{*}{ Uji Hipotesis } & $\begin{array}{c}\text { Standardized } \\
\text { Coefficients }\end{array}$ & $\begin{array}{c}\text { Nilai } \\
\boldsymbol{R} \\
\text { Square }\end{array}$ & $\begin{array}{c}\text { Nilai } \\
\mathbf{( p )} \\
\mathbf{0 , 0 5}\end{array}$ & Keterangan \\
\cline { 2 - 5 } & \multicolumn{1}{|c|}{ Beta } & & 0,011 & $\begin{array}{l}\text { Hipotesis } \\
\text { Diterima }\end{array}$ \\
\hline $\begin{array}{l}\text { Dukungan Pasangan } \rightarrow \text { Work-Family } \\
\text { Conflict }\end{array}$ & $-0,326$ & 0,028 & $\begin{array}{l}\text { Hipotesis } \\
\text { Diterima }\end{array}$ \\
\hline $\begin{array}{l}\text { Dukungan Organisasi } \rightarrow \text { Work-Family } \\
\text { Conflict }\end{array}$ & $-0,281$ & 0,240 & 0,001 & \\
\hline $\begin{array}{l}\text { Dukungan Pasangan \& Dukungan } \\
\text { Organisasi } \rightarrow \text { Work-Family Conflict }\end{array}$ & & & 0,768 & $\begin{array}{l}\text { Hipotesis } \\
\text { Ditolak }\end{array}$ \\
\hline $\begin{array}{l}\text { Dukungan Pasangan } \rightarrow \text { Stres Kerja } \\
\text { langsung) }\end{array}$ & 0,028 & 0,118 & $\begin{array}{l}\text { Hipotesis } \\
\text { Ditolak }\end{array}$ \\
\hline $\begin{array}{l}\text { Dukungan Organisasi } \rightarrow \text { Stres Kerja } \\
\text { langsung) }\end{array}$ & $-0,146$ & 0,000 & $\begin{array}{l}\text { Hipotesis } \\
\text { Diterima }\end{array}$ \\
\hline Work-Family Conflict $\rightarrow$ Stres Kerja & 0,737 & 0,628 & 0,000 & \\
\hline $\begin{array}{l}\text { Dukungan Pasangan, Dukungan } \\
\text { Organisasi, Work-Family Conflict } \rightarrow \\
\text { Stres Kerja }\end{array}$ & $-0,240$ & & & $\begin{array}{l}\text { Hipotesis } \\
\text { Diterima }\end{array}$ \\
\hline $\begin{array}{l}\text { Dukungan Pasangan } \rightarrow \text { Stres Kerja } \\
\text { tidak langsung) }\end{array}$ & $-0,268$ & & $\begin{array}{l}\text { Hipotesis } \\
\text { Diterima }\end{array}$ \\
\hline $\begin{array}{l}\text { Koefisien Dukungan Pasangan \& } \\
\text { Work-Family Conflict } \rightarrow \text { Stres Kerja }\end{array}$ & $-0,207$ & & & \\
\hline $\begin{array}{l}\text { Dukungan Organisasi } \rightarrow \text { Stres Kerja } \\
\text { tidak langsung) }\end{array}$ & $-0,353$ & & & \\
\hline $\begin{array}{l}\text { Koefisien Dukungan Organisasi \& } \\
\text { Work-Family Conflic } \rightarrow \text { Stres Kerja }\end{array}$ & & & & \\
\hline
\end{tabular}

Selanjutnya analisis jalur dalam penelitian ini terbagi dalam dua model, yakni jalur model I dan jalur model II. Hasil temuan menunjukan bahwa dukungan pasangan secara langsung berpengaruh negatif terhadap work-family conflict dengan nilai signifikansi $0,011<0,05$ dan 
koefisien $\beta$ sebesar $-0,326$. Hal ini menunjukan bahwa H1 diterima. Sementara dukungan organisasi juga secara langsung menunjukan pengaruh negatif terhadap work-family conflict dengan nilai signifikansi $0,028<0,05$ dan koefisien $\beta$ sebesar $-0,281$ sehingga dengan demikian $\mathrm{H} 2$ diterima. Secara simultan, pengaruh dukungan pasangan dan dukungan organisasi (residual) terhadap work-family conflict adalah $0,001<0,05$ dengan nilai $\mathrm{R}$ Square 0,240. Hal ini menunjukan bahwa sumbangan pengaruh kedua variabel terhadap work-family conflict adalah sebesar $24 \%$ dan sisanya $76 \%$ dipengaruhi oleh faktor lain yang tidak diteliti dalam penelitian ini.

Hasil temuan lainnya menunjukkan bahwa dukungan pasangan secara langsung tidak berpengaruh secara negatif terhadap stres kerja dengan nilai signifikansi 0,768 $>0,05$ dan nilai koefisien $\beta$ sebesar $-0,146$. Hasil analisis pengaruh negatif secara langsung dukungan organisasi terhadap stres kerja juga menunjukkan hal yang sama karena nilai signifikansi 0,118 > 0,05 dan nilai koefisien $\beta$ sebesar o,028. Dengan demikian, H3 dan H4 dalam penelitian ini ditolak karena baik dukungan pasangan maupun dukungan organisasi tidak memiliki pengaruh negatif secara langsung terhadap stres kerja. Sebaliknya, work-family conflict secara langsung berpengaruh positif terhadap stres kerja dengan nilai signifikansi $0,000<0,05$ dan nilai koefisien $\beta$ sebesar 0,737 yang artinya H5 diterima. Secara simultan, pengaruh dukungan pasangan, dukungan organisasi dan work-family conflict (residual) terhadap stres kerja adalah $0,000<0,05$ dengan nilai $\mathrm{R}$ Square sebesar 0,628 sehingga dapat disimpulkan bahwa sumbangan ketiga variabel terhadap stres kerja adalah sebesar $62,8 \%$ dan sisanya $37,2 \%$ dipengaruhi oleh faktor lain yang tidak diteliti dalam penelitian ini.

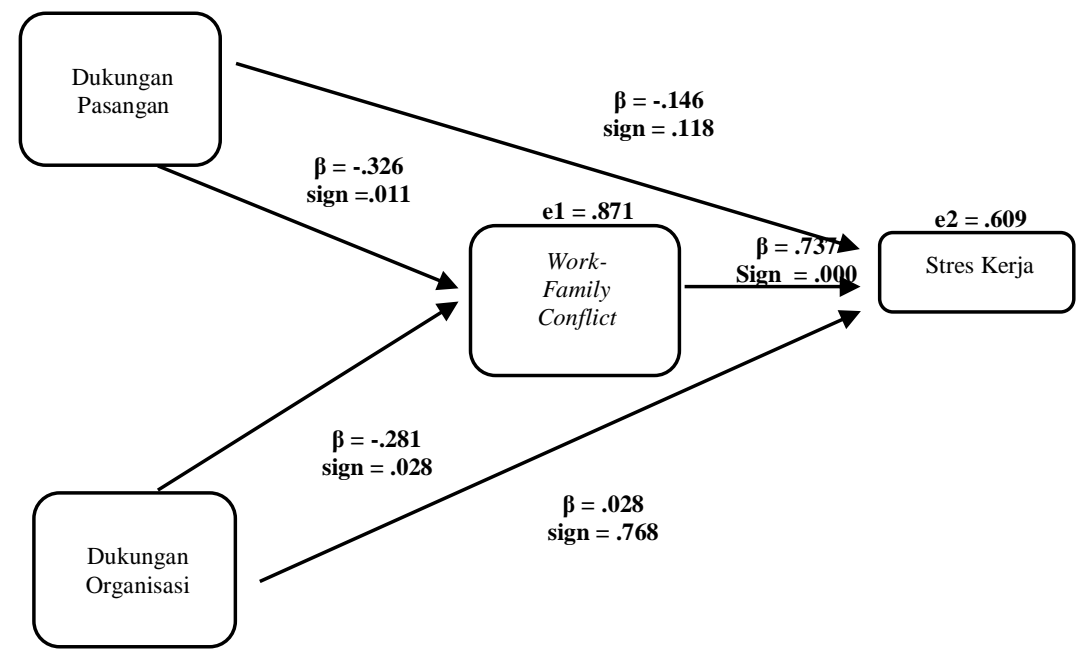

Gambar 1. Hasil Analisis Pengaruh Dukungan Pasangan dan Dukungan Organisasi terhadap Stres Kerja Melalui Mediasi Work-family conflict

Berdasarkan hasil temuan di atas, pengaruh langsung dukungan pasangan terhadap stres kerja memiliki nilai koefisien $\beta$ sebesar 0,028 , sementara pengaruh tidak langsung dukungan pasangan melalui work-family conflict terhadap stres kerja adalah hasil perkalian nilai koefisien $\beta$ dukungan pasangan terhadap work-family conflict $(-0,326)$ dengan nilai koefisien $\beta$ workfamily conflict terhadap stres kerja $(0,737)$, yakni sebesar -0,240. Dalam kasus ini, terjadi perubahan bentuk pengaruh langsung dukungan pasangan terhadap stres kerja yang bersifat positif (tidak signifikan) menjadi pengaruh negatif (signifikan) ketika dimediasi oleh workfamily conflict. Dengan demikian dapat disimpulkan bahwa work-family conflict menjadi mediator penuh antara dukungan pasangan dan stres kerja (H6 diterima). Total pengaruh yang 
diberikan dukungan pasangan terhadap stres kerja melalui work-family conflict adalah -0,268. Sementara pengaruh langsung dukungan organisasi terhadap stres kerja memiliki nilai koefisien $\beta$ sebesar $-0,146$ (tidak signifikan), sementara pengaruh tidak langsung dukungan organisasi melalui work-family conflict terhadap stres kerja adalah hasil daripada perkalian nilai koefisien $\beta$ dukungan organisasi terhadap work-family conflict $(-0,281)$ dengan nilai koefisien $\beta$ workfamily conflict terhadap stres kerja $(0,737)$, yakni sebesar -0,207 (signifikan). Dengan demikian work-family cocnflict menjadi mediator penuh antara dukungan organisasi dan stres kerja (H7 diterima). Total pengaruh yang diberikan dukungan organisasi terhadap stres kerja melalui work-family conflict adalah sebesar - 0,353 .

\section{Diskusi}

Pemberlakuan kebijakan bekerja dari rumah sejak terjadinya pandemi Covid-19 di Indonesia menyebabkan ibu yang menjalankan peran ganda semakin sulit karena bertambahnya bebab kerja-terutama pada pekerjaan tidak berbayar atau rumah tangga(Craig \& Churchill, 2020), terbatasnya sumber daya-baik secara makro seperti sekolah atau tempat penitipan anak, maupun kontekstual seperti bantuan keluarga besar, saudara atau lingkaran pertemanan dan tetangga menjadi terputus karena pembatasan sosial (Chung, Lanier, et al., 2020), serta adanya gender gap sebagai implikasi daripada faktor budaya patriarki yang menyebabkan timpangnya pembagian tugas pekerjaan rumah tangga (Chairani, 2020). Dalam konsepsi work-home resources (W-HR), tuntutan-tuntutan kontekstual demikian mempengaruhi hasil work-home interface dan akhirnya menyebabkan terjadinya konflik pekerjaan-keluarga atau work-family conflict serta meningkatkan kecenderungan untuk mengalami stres kerja yang tinggi (Brummelhuis \& Bakker, 2012).

Namun demikian, hasil daripada penelitian ini menunjukkan bahwa work-family conflict yang dialami oleh ibu yang bekerja di rumah selama Covid-19 paling banyak berada pada kategori sedang $(66,7 \%)$, sementara tingkat stres kerja paling banyak juga berada pada kategori sedang $(64,9 \%)$. Hal ini mengindikasikan bahwa selain tuntutan-tuntutan kontekstual yang mempengaruhi work-family conflict dan stres kerja, terdapat faktor lain seperti sumber daya kontekstual yang mempengaruhi hasil tersebut (Brummelhuis \& Bakker, 2012). Sumber daya kontekstual yang diteliti dalam studi ini adalah dukungan pasangan yang berasal dari domain rumah (home) dan dukungan organisasi yang berasal dari domain pekerjaan (work). Kedua sumber daya tersebut merupakan dua hal yang masih dimiliki oleh ibu yang bekerja di rumah pada situasi pandemi Covid-19 ini. Berdasarkan hasil temuan, dukungan pasangan dan dukungan organisasi yang diterima oleh ibu yang bekerja di rumah selama Covid-19 paling banyak berada pada kategori sedang (dukungan pasangan $71,9 \%$ dan dukungan organisasi $64,9 \%$ ) pada masing-masing variabel.

Penelitian ini menganalisis lebih jauh bagaimana pengaruh dukungan pasangan dan dukungan organisasi terhadap stres kerja melalui mediasi work-family conflict. Terdapat tujuh hipotesis diajukan dalam penelitian ini untuk kemudian dianalisis menggunakan analisis jalur (path analysis). Berdasarkan hasil temuan (H1 \& $\mathrm{H} 2$ diterima), dukungan pasangan dan dukungan organisasi berpengaruh negatif secara langsung terhadap work-family conflict, yang artinya bahwa semakin tinggi tingkat dukungan pasangan dan dukungan organisasi yang terima maka semakin rendah tingkat work-family conflict yang dirasakan oleh ibu yang bekerja di rumah selama pandemi Covid-19. Temuan ini sejalan dengan penelitian yang dilakukan oleh Aycan \& Eskin (2005) yang juga menunjukkan bahwa dukungan pasangan memiliki hubungan yang erat secara negatif dengan work-family conflict. Penelitian lain yang mendukung hasil temuan terkait pengaruh dukungan pasangan terhadap work-family conflict adalah penelitian Burke \& Greenglass (1999) serta Erdwins et al., (2001). Penelitian Halbesleben et al., (2012) menemukan bahwa dukungan pasangan dapat mengurangi berbagai hasil negatif (misalnya work-family conflict) dan dapat menjadi sumber daya yang sangat penting bagi mereka yang 
menjalankan peran ganda seperti ibu yang bekerja. Sementara beberapa penelitian lain yang sejalan dengan dukungan organisasi dalam pengaruhnya terhadap work-family conflict adalah Penelitian Turner \& Mariani (2016) yang menunjukkan bahwa dukungan organisasi memainkan peran penting terhadap karyawan dalam menyeimbangkan pekerjaan dan tanggung jawab keluarga. Penelitian yang dilakukan oleh Anderson (2017) menjelaskan bahwa dukungan organisasi secara signifikan dapat menurunkan tingkat work-family conflict pada karyawan yang memiliki peran ganda.

Selanjutnya, penelitian ini juga menemukan bahwa dukungan pasangan dan dukungan organisasi tidak berpengaruh negatif secara langsung terhadap stres kerja (H3 \& H4 ditolak). Hasil ini berbeda dengan hipotesis yang diajukan dan beberapa penelitian sebelumnya. Penelitian Adams et al., (1996) serta Burke \& Richardsen (2016) menjelaskan bahwa dukungan pasangan memainkan peran penting dalam mengurangi efek stres kerja. Hal ini bisa jadi sebabkan oleh faktor gender antara laki-laki dan perempuan. Penelitian Bures et al., (2011) menguji perbedaan tingkat stres kerja antara laki-laki dan perempuan ditinjau dari dukungan pasangan yang diterima dan hasilnya menunjukkan bahwa dukungan pasangan mampu menurunkan stres kerja pada laki-laki hingga $40 \%$ sementara pada perempuan hanya $17 \%$. Namun demikian, penelitian ini tidak menguji perbedaan gender tersebut karena hanya melibatkan responden dengan jenis kelamin perempuan.

Pengaruh dukungan organisasi terhadap stres kerja juga berbeda dengan penelitian sebelumnya. Penelitian Leung et al., (2008) menunjukkan bahwa dukungan organisasi merupakan salah satu faktor yang efektif dalam mengurangi stres kerja dan kelelahan kerja (burnout) yang dialami oleh karyawan. Hal ini bisa jadi disebabkan oleh perbedaan gaya kerja antara bekerja dari rumah (WFH) dan bekerja dari kantor (WFO). Misalnya, peran dukungan organisasi tidak bisa dimaksimalkan karena organisasi tidak mampu melihat perilaku kerja (misalnya perilaku stres dan kepuasan kerja) karyawan-karyawannya secara langsung. Penelitian sebelumnya (Leung et al., 2008) dilakukan pada responden yang bekerja di kantor, sementara penelitian ini melibatkan responden yang bekerja dari rumah. Namun demikian, penelitian ini juga tidak menguji perbedaan variabel tersebut.

Temuan pengaruh positif langsung work-family conflict terhadap stres kerja sejalan dengan penelitian sebelumnya (H5 diterima). Beberapa penelitian yang sejalan dengan temuan ini adalah penelitian yang dilakukan Agustina \& Sudibya (2018) yang menyatakan bahwa workfamily conflict berpengaruh secara positif dengan stres kerja dan menjadi variabel mediasi dalam mempengaruhi secara negatif terhadap kinerja seseorang dalam pekerjaannya dalam taraf yang signifikan. Penelitian lainnya yang menunjukan hasil yang sama adalah penelitian Gusti et al., (2016), Jamadin et al., (2015), Bazana \& Dodd (2013) serta Hammer et al., (1996) yang kesemuanya menunjukan pengaruh positif antara work-family conflict dengan stres kerja. Dalam hal ini, dapat disimpulkan bahwa semakin tinggi tingkat work-family conflict, semakin tinggi pula stres kerja dirasakan oleh ibu yang bekerja di rumah selama pandemi Covid-19.

Terakhir, penelitian ini menemukan bahwa dukungan pasangan dan dukungan organisasi berpengaruh secara negatif terhadap stres kerja melalui mediasi work-family conflict. Penelitian yang dilakukan oleh Brummelhuis \& Bakker (2012) terkait work-home resources (WHR)-pengembangan teori COR (Hobfoll, 2002)-menunjukan bahwa sumber daya-sumber daya (personal, kontekstual, macro dan kunci) mempengaruhi hasil work-home interface dan akhirnya menyebabkan terjadinya work-family conflict serta meningkatkan kecenderungan untuk mengalami stres. Dalam hal ini, dukungan pasangan dan dukungan organisasi yang merupakan bagian dari sumber daya kontekstual dapat mengurangi stres kerja secara tidak langsung melalui work-family conflict yang dialami. Oleh sebab itu, tingkat stres kerja dan work-family conflict pada ibu yang bekerja selama pandemi Covid-19 rata-rata berada di tingkat 
yang sedang karena dukungan pasangan dan dukungan organisasi yang selama ini mereka alami juga rata-rata berada di tingkat yang sedang. Lebih jauh, penelitian Brummelhuis \& Bakker (2012) juga menjelaskan bahwa sumber daya satu dapat mempengaruhi sumber daya lainnya. Penelitian yang dilakukan oleh Nagarajan (2016) dan Siu et al., (2010) menemukan bahwa dukungan pasangan memediasi work-home enrichment pada stres kerja. Hal ini menunjukkan bahwa seseorang yang menerima dukungan pasangan dapat menggunakan sumber daya ini untuk menahan stres yang muncul atau meningkatkan sumber daya lain, misalnya sumber daya personal seperti energi dan motivasi untuk melaksanakan tanggung jawabnya sebagai orang tua, pasangan, atau pun pekerja.

\section{PENUTUP}

\section{Simpulan}

Penelitian ini membuktikan work-family conflict mempengaruhi stres kerja secara dominan pada ibu bekerja di rumah selama pandemi Covid-19. Berdasakan hasil temuan, pengaruh work-family conflict dalam penelitian ini mencapat $63 \%$. Hasil temuan tersebut selaras dengan banyaknya penelitian-penelitian terdahulu yang mengkaji hubungan positif antara workfamily conflict dan stres kerja dalam berbagai setting atau konteks. Namun demikian, penelitianpenelitian terdahulu hanya mengkaji keterkaitan tersebut secara parsial sehingga sulit untuk menemukan faktor-faktor apa saja yang mempengaruh work-family conflict dan implikasinya secara khusus terhadap stres kerja.

Penelitian ini menjadi penting karena mengajukan model struktur kausalitas baru dengan mengkaji peran dukungan pasangan dan dukungan organisasi sebagai sumber daya kontekstual dalam model work-home resource (W-HR) dan hubungannya dengan work-family conflict dan stres kerja. Hasilnya, dukungan pasangan dan dukungan organisasi berpengaruh negatif secara langsung terhadap work-family conflict, namun tidak memiliki pengaruh negatif langsung terhadap stres kerja. Selanjutnya, dukungan pasangan dan dukungan organisasi berpengaruh negatif secara tidak langsung terhadap stres kerja melalui mediasi work-family conflict dengan rata-rata berada di tingkat sedang untuk setiap variabel tersebut. Dengan demikian dapat dapat disimpulkan bahwa dukungan pasangan dan dukungan organisasi dapat menekan tingkat workfamily conflict dan selanjutnya menekan tingkat stes kerja yang dialami oleh ibu bekerja di rumah selama pandemi Covid-19.

\section{Saran}

Perusahaan atau organisasi harus memberikan perhatian khusus terhadap hal ini untuk meningkatkan dukungan pasangan dan dukungan organisasi agar dapat menekan tingkat workfamily conflict dan stres kerja karyawannya untuk selanjutnya meningkatkan kinerja dan produktivitas. Beberapa hal yang bisa dilakukan oleh perusahaan atau organisasi untuk meningkatkan dukungan pasangan adalah dengan memberikan program khusus kepada karyawan berupa pelatihan manajemen konflik keluarga, manajemen stres atau pun manajemen waktu agar dapat meningkatkan keseimbangan antara kerja dan kehidupan pribadi. Sementara dukungan organisasi dapat lebih dimaksimalkan dengan meregulasi ulang kebijakan perusahaan terkait fleksibilitas waktu kerja, penyesuaian beban kerja dan target kinerja, serta memberikan dukungan moral yang lebih terhadap karyawan yang mengalami masalah terkait untuk meningkatkan kepuasan kerja.

Keterbatasan waktu penelitian menyebakan penelitian ini hanya melibatkan 57 responden dan tidak terdistribusi dengan merata karena didominasi oleh responden yang berdomisili di daerah Bogor. Penelitian ini juga hanya melibatkan responden dari jenis kelamin perempuan sesuai dengan tujuannya dan tidak melibatkan responden laki-laki. Penelitian selanjutnya diharapkan dapat melibatkan lebih banyak variasi responden agar dapat dilakukan perbandingan 
untuk mendapatkan analisis yang lebih komprehensif. Secara konseptual, penelitian ini hanya meneliti aspek dukungan pasangan dan dukungan organisasi (sumber daya kontekstual) yang merupakan bagian kerangka work-home resources (W-HR), sementara masih banyak aspek atau sumber daya lain yang masih belum ditinjau. Penelitian selanjutnya diharapkan bisa meninjau lebih banyak aspek dan sumber daya dalam konsep work-home resources model (WHR) baik dari segi faktor maupun implikasinya.

\section{REFERENSI}

Adams, G. A., King, L. A., \& King, D. W. (1996). Relationships of Job and Family Involvement, Family Social Support, and Work-Family Conflict with Job and Life Satisfaction. In Journal of Applied Psychology (Vol. 81, Issue 4). DOI. https://psycnet.apa.org/record/1997-41277-007

Agustina, R., \& Sudibya, I. G. A. (2018). Pengaruh Work Family Conflict Terhadap Stres Kerja Dan Kinerja Wanita Perawat Di Rumah Sakit Umum Daerah Praya Lombok. E-Jurnal $\begin{array}{llll}\text { Ekonomi Dan Bisnis Universitas } & \end{array}$ https://doi.org/10.24843/eeb.2018.v07.i03.p06

Anderson, M. (2017). Transformational Leadership in Education: A Review of Existing Literature. International Social Science Review, 93(1), 4.

Aycan, Z., \& Eskin, M. (2005). Relative Contributions of Childcare, Spousal Support, and Organizational Support in Reducing Work-Family Conflict for Men and Women: The Case of Turkey 1. Sex Roles, 53. https://doi.org/10.1007/s11199-005-7134-8

Badan Pusat Statistik. (n.d.). Retrieved February 19, 2021, from https://www.bps.go.id/publication/2020/06/01/669cb2e8646787e52dd171c4/hasil-surveysosial-demografi-dampak-covid-19.html

Bazana, S., \& Dodd, N. (2013). Conscientiousness, Work Family Conflict and Stress amongst Police Officers in Alice, South Africa. Journal of Psychology, 4(1), 1-8. https://doi.org/10.1080/09764224.2013.11885487

Bohen, H., \& Viveros-Long, A. (1981). Balancing jobs and family life. https://agris.fao.org/agris-search/search.do?recordID=US201300392963

Bures, A. L., Henderson, D., Mayfield, J., Mayfield, M., \& Worley, J. (2011). The Effects Of Spousal Support And Gender On Workers Stress And Job Satisfaction: A Cross National Investigation Of Dual Career Couples. Journal of Applied Business Research (JABR), 12(1), 52. https://doi.org/10.19030/jabr.v12i1.5837

Burke, R. J., \& Greenglass, E. R. (1999). Work-Family Conflict, Spouse Support, and Nursing Staff Well-Being During Organizational Restructuring. In Journal of Occupational Health Psychology (Vol. 4, Issue 4). https://psycnet.apa.org/record/1999-11425-004

Burke, R. J., \& Richardsen, A. M. (2016). Women in management worldwide: Signs of progress. In Women in Management Worldwide: Signs of Progress. https://doi.org/10.4324/9781315546742

Burke, R. J., \& Traavik, L. E. M. (2016). Women and work stress: More and different? In Handbook on Well-Being of Working Women (pp. 123-140). Springer Netherlands. https://doi.org/10.1007/978-94-017-9897-6_8

Chairani, I. (2020). Dampak Pandemi Covid-19 Dalam Perspektif Gender Di Indonesia. Jurnal Kependudukan Indonesia, 39. https://doi.org/10.14203/jki.v0i0.571

Chandola, T., Booker, C. L., Kumari, M., \& Benzeval, M. (2020). Are Flexible Work Arrangements Associated with Lower Levels of Chronic Stress-Related Biomarkers? A Study of 6025 Employees in the UK Household Longitudinal Study. Sociology, 53(4), 779-799. https://doi.org/10.1177/0038038519826014

Chung, G., Chan, X. W., Lanier, P., \& Ju, P. W. Y. (2020). Associations Between Work-Family Balance, Parenting Stress, and Marital Conflicts During COVID-19 Pandemic in Singapore. https://doi.org/10.31219/osf.io/nz9s8 
Chung, G., Lanier, P., \& Wong, P. Y. J. (2020). Mediating Effects of Parental Stress on Harsh Parenting and Parent-Child Relationship during Coronavirus (COVID-19) Pandemic in Singapore. Journal of Family Violence. https://doi.org/10.1007/s10896-020-00200-1

Coyne, L. W., Gould, E. R., Grimaldi, M., Wilson, K. G., Baffuto, G., \& Biglan, A. (2020). First Things First: Parent Psychological Flexibility and Self-Compassion During COVID19. Behavior Analysis in Practice. https://doi.org/10.1007/s40617-020-00435-w

Craig, L., \& Churchill, B. (2020). Dual-earner Parent Couples' Work and Care during COVID19. Wiley Online Library. https://doi.org/10.1111/gwao.12497

Eisenberger, R., Huntington, R., Hutchison, S., \& Sowa, D. (1986). Perceived Organizational Support. In Journal of Applied Psychology (Vol. 71, Issue 3). https://psycnet.apa.org/doiLanding?doi=10.1037/0021-9010.71.3.500

Erdwins, C. J., Buffardi, L. C., Casper, W. J., \& O'Brien, A. S. (2001). The relationship of women's role strain to social support, role satisfaction, and self-efficacy. Family Relations, 50(3), 230-238. https://doi.org/10.1111/j.1741-3729.2001.00230.x

Gusti, I., Gede, A., Divara, K., \& Rahyuda, A. G. (2016). Pengaruh Work Family Conflict Terhadap Stres Kerja Dan Komitmen Organisasional Pegawai Kontrak Dinas Kebudayaan Provinsi Bali. Ocs.Unud.Ac.Id, 5(11), 6994-7021. https://ocs.unud.ac.id/index.php/Manajemen/article/view/23848

Halbesleben, J. R. B., Wheeler, A. R., \& Rossi, A. M. (2012). The costs and benefits of working with one's spouse: A two-sample examination of spousal support, work-family conflict, and emotional exhaustion in work-linked relationships. Journal of Organizational Behavior, 33(5), 597-615. https://doi.org/10.1002/job.771

Hammer, T. H., Saksvik, Ø., Nytrø, K., \& Torvatn, H. (1996). Expanding the Psychosocial Work Environment: Workplace Norms and Work-Family Conflict as Correlates of Stress and Health. Johnson \& Hall, 9(1), 83-97. https://doi.org/10.1037/1076-8998.9.1.83

Hao, J., Wang, J., Liu, L., Wu, W., \& Wu, H. (2016). Perceived Organizational Support Impacts on the Associations of Work-Family Conflict or Family-Work Conflict with Depressive Symptoms among Chinese Doctors. Mdpi.Com. https://doi.org/10.3390/ijerph13030326

Hobfoll, S. E. (2002). Social and Psychological Resources and Adaptation. Article in Review of General Psychology, 6(4), 307-324. https://doi.org/10.1037/1089-2680.6.4.307

Jamadin, N., Mohamad, S., Syarkawi, Z., \& Noordin, F. (2015). Work - Family Conflict and Stress: Evidence from Malaysia. Journal of Economics, Business and Management, 3(2), 309-312. https://doi.org/10.7763/joebm.2015.v3.200

King, L. A., Mattimore, L. K., King, D. W., \& Adams, G. A. (1995). Family Support Inventory for Workers: A new measure of perceived social support from family members. Journal of Organizational Behavior, 16(3), 235-258. https://doi.org/10.1002/job.4030160306

Kopelman, R. E., Greenhaus, J. H., \& Connolly, T. F. (1983). A model of work, family, and interrole conflict: A construct validation study. Organizational Behavior and Human Performance, 32(2), 198-215. https://doi.org/10.1016/0030-5073(83)90147-2

Leung, M., Zhang, H., \& Skitmore, M. (2008). Effects of Organizational Supports on the Stress of Construction Estimation Participants. Journal of Construction Engineering and Management, 134(2), 84-93. https://doi.org/10.1061/(asce)0733-9364(2008)134:2(84)

Lleras, C. (2004). Path Analysis. In Encyclopedia of Social Measurement (pp. 25-30). https://doi.org/10.1016/B0-12-369398-5/00483-7

Megatsari, H., Laksono, A. D., Ibad, M., Herwanto, Y. T., Sarweni, K. P., Geno, R. A. P., \& Nugraheni, E. (2020). The community psychosocial burden during the COVID-19 pandemic in Indonesia. Heliyon, 6(10). https://doi.org/10.1016/j.heliyon.2020.e05136

Morelli, M., Cattelino, E., Baiocco, R., Trumello, C., Babore, A., Candelori, C., \& Chirumbolo, A. (2020). Parents and Children During the COVID-19 Lockdown: The Influence of Parenting Distress and Parenting Self-Efficacy on Children's Emotional Well-Being. Frontiers in Psychology, 11. https://doi.org/10.3389/fpsyg.2020.584645

Nagarajan, G. (2016). The Role of Self-Efficacy and Social Support in Improving Life 
Satisfaction: The Mediating Role of Work-Family Enrichment Work Family Enrichment and Work Family Conflict View project uncertainities of Aviation View project. Econtent.Hogrefe.Com, 224(1), 25-33. https://doi.org/10.1027/2151-2604/a000235

Power, K. (2020). The COVID-19 pandemic has increased the care burden of women and families. Taylor \& Francis, 16(1), 67-73. https://doi.org/10.1080/15487733.2020.1776561

Shukla, A., \& Srivastava, R. (2016). Development of short questionnaire to measure an extended set of role expectation conflict, coworker support and work-life balance: The new job stress scale. Cogent Business and Management, 3(1). https://doi.org/10.1080/23311975.2015.1134034

Siu, O. ling, Lu, J. fang, Brough, P., Lu, C. qin, Bakker, A. B., Kalliath, T., O’Driscoll, M., Phillips, D. R., Chen, W. qing, Lo, D., Sit, C., \& Shi, K. (2010). Role resources and workfamily enrichment: The role of work engagement. Journal of Vocational Behavior, 77(3), 470-480. https://doi.org/10.1016/j.jvb.2010.06.007

Survei Dampak Darurat Virus Corona terhadap Tenaga Kerja Indonesia | Lembaga Ilmu Pengetahuan Indonesia. (n.d.). Retrieved February 19, 2021, from http://lipi.go.id/berita/single/Survei-Dampak-Darurat-Virus-Corona-terhadap-TenagaKerja-Indonesia/22030

ten Brummelhuis, L. L., \& Bakker, A. B. (2012). A resource perspective on the work-home interface: The work-home resources model. American Psychologist, 67(7), 545-556. https://doi.org/10.1037/a0027974

Thomas, L. T., \& Ganster, D. C. (1995). The relationship between work-family role conflict, family supportive work policies and stress: A control perspective. Journal of Applied Psychology, 80(1), 6-15. https://www.researchgate.net/publication/35563431

Turner, M., \& Mariani, A. (2016). Managing the work-family interface: experience of construction project managers. International Journal of Managing Projects in Business, 9(2), 243-258. https://doi.org/10.1108/IJMPB-07-2015-0057

Wu, G., Wu, Y., Li, H., \& Dan, C. (2018). Job burnout, work-family conflict and project performance for construction professionals: The moderating role of organizational support. International Journal of Environmental Research and Public Health, 15(12). https://doi.org/10.3390/ijerph15122869

Yang, F., Li, X., Song, Z., Li, Y., \& Zhu, Y. (2018). Job Burnout of Construction Project Managers: Considering the Role of Organizational Justice. Journal of Construction Engineering and Management, 144(11), 04018103. https://doi.org/10.1061/(asce)co.19437862.0001567 